\title{
Principles for the Safe Moving and Handling of Patients
}

Zasady bezpiecznego podnoszenia i przemieszczania pacjentów

\section{Stephen Wanless}

\author{
Clinical Biomechanics and Musculoskeletal Injury Prevention, Clinical Director Centre of Excellence in Posture, Movement and Handling \\ Birmingham City University, Faculty of Health, Education and Life Sciences \\ CORRESPONDING AUTHOR/AUTOR DO KORESPONDENCJ: \\ Stephen Wanless \\ Birmingham City University, Faculty of Health, Room 454 Seacole Building, City South Campus \\ Westbourne Road, Edgbaston, Birmingham. B15 3TN. \\ e-mail: stephen.wanless@bcu.ac.uk
} tel. 01213317069

ABSTRACT

Key words:

STRESZCZENIE

Słowa kluczowe:

\section{PRINCIPLES FOR THE SAFE MOVING AND HANDLING OF PATIENTS}

Human movement when walking or running is a widely researched area. However, there is an increased incidence of musculoskeletal injury from poor positioning when moving and handling patients amongst healthcare professionals and is one of the main causes of long term musculoskeletal health problems. In the clinical area, an individual's musculoskeletal health system is subjected to mechanical loading, increasing the body's stress and strain limits, and once these are exceeded injury occurs. The risk of pain and injury has a direct relation from the over use of poor posture from poor moving and handling, which in turn can cause loss of strength and reduce musculoskeletal function. This can be changed through healthcare workers adopting safe biomechanical body movements during patient handling tasks.

\section{Posture, Musculoskeletal Injury, body mechanics, Moving and Handling}

\section{ZASADY BEZPIECZLNECOPODNOSZZNNA I PRZEMIESZCZANIA PACJENTÓW}

Sposób poruszania się człowieka podczas chodzenia czy biegania jest częstym przedmiotem badań naukowych. Stwierdzono jednak zwiększoną częstość występowania urazów narządu ruchu spowodowanych nieodpowiednim podnoszeniem i przemieszczaniem pacjentów przez pracowników służby zdrowia. Jest to jedna z głównych przyczyn długotrwałych problemów układu mięśniowoszkieletowego. W obszarze klinicznym układ ten ulega obciążeniom mechanicznym, zwiększając tym samym ograniczenia związane z naprężeniem i napięciem ciała, a gdy ograniczenia te zostają przekroczone, wtedy następuje uraz. Ryzyko bólu i urazu ma bezpośredni związek z nadużywaniem nieodpowiedniej pozycji przy podnoszeniu i przemieszczaniu pacjentów, co z kolei może prowadzić do utraty przez nich sił i zmniejszenia funkcji układu mięśniowo-szkieletowego. Sytuacja ta może ulec zmianie poprzez dostosowanie bezpiecznych biomechanicznych sposobów przemieszczania ciała pacjenta przez pracowników służby zdrowia.

postawa, uraz układu mięśniowo-szkieletowego, mechanika ciała, podnoszenie i przemieszczanie

\section{INTRODUCTION}

One of the most studied areas of human movements is that of dynamic movement when walking or running $[1,2,3]$. The incidence of musculoskeletal injury amongst healthcare professionals is still one of the main causes of long term health problems in the United Kingdom [4]. The musculoskeletal system is constantly subjected to mechanical loading with bones, cartilages, ligaments and tendons having stress and strain limits, and once these are exceeded injury can start to occur [3]. Thus, the incidence of pain and injury has a direct relation with overloading and poor posture from poor moving and handling, which in turn can cause loss of strength and posture function [5].

Back pain is an international economic and social issue within healthcare. It is the main reason stated for sickness and absence and is a significant occupational health problem that has an influence in all areas of health care provision [6]. Ergonomic and musculoskeletal problems are regarded as the leading occupational issue affecting the global healthcare workforce [7]. Healthcare workers constantly rank amongst the main occupations with permanent back injuries in particular that of the lower back $[3,4]$, which occur mainly from the handling of patients. Back pain studies in healthcare workers have shown a correlation between the symptoms of back pain and being in a poor posture [8], from lifting clients and patients [9] and musculoskeletal stress in the workplace [10].

\section{DISCUSSION}

This can be changed through healthcare workers developing safe biomechanical body movements during patient handling tasks [5]. Normally, a generic one size fits all training programme has been used to address the problems of musculoskeletal injury when patient handling [5] as it offers a simple option for employers to ensure productivity 
[8]. Hignett [11] found in a systematic review on twelve studies related to the moving and handling of patients, that a programme that used technique driven training made no impact on moving and handling culture or the associated injury statistics. The moving and handling of patients involves the moving of heavy loads and studies have noted that this is a contributing factor in the development of lower back pain $[3,4]$. It is not surprising that low back pain and lower back injuries are the most common kind of musculoskeletal problems caused by moving and handling. These are significant and an increasing issue within European member states [12]. Back pain is a leading work related health issue (23.8\%) in the European Union, with a higher rate of work aged people $(38.9 \%)$ affected within the new Member States [13]. These injuries may have serious repercussions to healthcare workers and can reduce their ability to undertake a wide range of social and work activities for the rest of their lives. Back problems and other musculoskeletal disorders are one of the main reasons for the current and increasing shortage of healthcare workers, therefore, giving them help to prevent injury is crucial.

A report released by the Royal College of Physicians in the UK [14] highlighted the need for healthcare workers to be advised on how to reduce back injury and pain. Musculoskeletal disorders such as lower back injury account for forty percent of sickness and absence amongst healthcare staff and costs approximately $£ 400$ million per year. The Royal College of Physicians' National clinical audit of back pain management looked at how occupational health professionals cared for healthcare staff that were experiencing back injury and pain. The report showed that the care and advice given to staff suffering with back pain had improved since the previous audit in 2008. In fifty percent of the 5,524 cases included in the audit, people required better education about how to deal with back pain.

Based on previous statistics, one of the UK's largest trade unions, who represent staff who provide public services [15] predicted that about 3,600 healthcare workers have to retire every year due to debilitating back injuries caused by poor posture and movement. Around eighty percent of the population can develop lower back problems at some point during their life due to poor posture. Across the healthcare environment, over a quarter of reported injuries of healthcare workers are related to the moving and handling of patients and inanimate loads. Registered nurses in the UK are the fifth on a top ten list of "at risk" occupations for musculoskeletal injuries despite having moving and handling training [4]. The risk of back injury due to poor posture and unsafe moving and handling affects all industries. As a whole, nurses account for eleven percent of the total $(1,887)$. The combined rate of injuries for these occupations was 124.5 per 100,000 employees. Health and social care, manufacturing and transportation and storage together account for more than fifty percent of the reported moving and handling injuries [4], the economic responsibility imposed is massive and several strategies have been attempted with an aim to prevent musculoskeletal injuries in this area.

In light of the above data it would seem that the traditional technique driven approaches on training healthcare workers in patient handling that are still widely used have been ineffective at reducing injuries [5]. Healthcare workers may be shown and taught all the patient handling procedures required for handling patients however, this does not ensure that a safe position will be adopted in order to perform the handling task. Without encompassing and using the basic principles of movement and handling, the safety of staff and patients will always be compromised. Healthcare workers who follow the principles may still injure themselves as the patient can be unpredictable, however adopting the correct position for handling will help to negate the risk of any injury.

Safe moving and handling of patients is not just about how the basic principles are applied to patient handling tasks. The principles of patient handling should be incorporated into a safety culture that is implemented from the top level of any organisation that supports and recognises the provision of moving and handling training and the supply of the correct and appropriate level of equipment needed.

Healthcare workers are exposed to high levels of patient handling as part of their daily routine [16]. Unlike many other areas healthcare professionals are required to perform varied practices that include many different aspects. The main different aspect that health care workers are subject to involves the movement of people not just inanimate loads. When handling a person many factors that can increase the risk of a back injury must be taken into consideration including the weight, shape and size of the patient, their capability, age and if they will co-operate [16].

Anecdotal evidence shows that a historical culture still remains within the healthcare sector to manually lift patients [5]. Time pressures, expectation from the patient or relatives, lack of equipment, perceived lack of patient cooperation or other factors are cited by healthcare workers as the reasons that encourage the handler to lift the patient. Healthcare workers may perform an unsafe procedure due to the caring nature of the profession consequently any patient in discomfort requires intervention. There are certain specific issues relating to the handling of patients which bring forward certain concerns. Examples of areas of concern include: Static positioning during patient handling, twisting and dealing with characteristics other than the patient's condition e.g. friable skin, osteoporosis, fractures, reflexes or emergency situations. There has to be an acceptance by the handler and the employer that a safe culture has to be recognised and implemented from the top of any organisation. To ensure that members of staff who are required to move and handle patients are working to a safe working practice the organisation must have a policy with the roles and responsibilities of all levels of staff contained within it.

The individual handler's principles of patient handling start prior to the task by the undertaking of a personal risk assessment. Patient handling requires a blend of common sense and being adaptable to any unusual situations that may occur. Due to the fact that the load to be moved is unpredictable every patient handling task is unique as no two patients are the same and a patient's condition does not stay the same indefinitely. Circumstances can change within a very short time therefore it is necessary to stop and conduct a personal risk assessment prior to each moving and handling task. The principles of safe patient handling start with a personal 
risk assessment and the question to stop and think is there a reason for handling or is the task being performed without a correct reason for moving the patient, remember every time a healthcare worker places their hands on a patient to assist or transfer them they are at risk of injury.

The overall aim and objective of any patient handling task should always be the first consideration. Moving and handling should only be carried out if there is no other way to achieve the objective, this will help to ensure that the handler will not put themselves at risk. Once it has been accepted that there is a clear objective then a personal risk assessment should be conducted that takes into consideration the following areas the Task, Individual capability, Load and to ensure they perform the moving and handling safely. On completion of the assessment the question that needs to be answered is "Can I or we perform this procedure safely - Yes or No?'

The questions that should be considered when moving a patient should be addressed using the acronym T. I. L. E. This will ensure a safe outcome to the patient handling task and should include:-

Tab. 1. Risk Assessment of moving and handling task.

\begin{tabular}{|l|l|}
\hline $\begin{array}{l}\text { Task and what it } \\
\text { involves }\end{array}$ & Does this task need to be undertaken or can it be avoided \\
\hline $\begin{array}{l}\text { Individual capability } \\
\text { of handlers }\end{array}$ & $\begin{array}{l}\text { Is everyone physically fit, are there any medical or } \\
\text { physical conditions that may affect ability, are there } \\
\text { any height constraints, age constraints, have all parties } \\
\text { been trained, does clothing hinder movement or } \\
\text { posture and is there any special strength required to } \\
\text { perform the task. }\end{array}$ \\
\hline Load-the Patient & $\begin{array}{l}\text { Their capability, their weight shape and size, are they } \\
\text { difficult to get hold of, are they easily managed both } \\
\text { physically and mentally, are they an unbalanced or an } \\
\text { unstable load, are they awkward, do we need special } \\
\text { information about the load, the patient's position } \\
\text { and the patient clothing. Encourage the patient to } \\
\text { contribute to each stage of the procedure. }\end{array}$ \\
\hline $\begin{array}{l}\text { Space constraints, slippery floors or different flooring, } \\
\text { furniture, cluttered areas, blocked passageways, poor } \\
\text { lighting, going up and down stairs, slopes. } \\
\text { Equipment }\end{array}$ & $\begin{array}{l}\text { Is the equipment correct for the procedure? Is the } \\
\text { equipment in safe working order? Has the equipment } \\
\text { been inspected? What is the safe working load? }\end{array}$ \\
\hline
\end{tabular}

When working with colleagues, in order to ensure that all of the above is taken into consideration, it is necessary to elect a team leader whose role is to plan the task and give clear and concise instructions. Communicating with colleagues and the patient is paramount to ensure safe movement. Communicating and preparing is the role of the team leader. A full explanation of the task should be discussed with the patient in order to encourage the patient to assist if they are able to do so. However, the handlers are in charge of the movement so if the patient decides to do their own movement then a full explanation must be repeated. A patient should never be allowed to take charge of an assisted movement. Once the patient is prepared the handlers then prepare the equipment and the environment carefully removing all hazards not only in the handling area but also along the route taken if transferring a patient. If time has elapsed the patient may have forgotten the first explanation, another explanation of what will happen and what is expected, of the patient should be undertaken again.

Once all of the above has been undertaken the handlers must concentrate on body position and posture required for the task. There are several factors that need to be considered in order to reduce the risk of injury.

Controlling centre of gravity by maintaining a natural body alignment: - Natural Body Alignment is the body's natural position fully supported by the core muscle system from which all movement begins and ends. A side view of the body in a functional design posture shows the following:-

Tab. 2. Side view of the body in a functional design posture.

\begin{tabular}{|l|l|}
\hline Back & $\begin{array}{l}\text { Shoulder, Hip, knee and ankle joints vertically aligned } \\
\text { with the line of gravity. } \\
\text { The pelvis in neutral alignment to support the "S" curve } \\
\text { of the spine and ready to move the body. }\end{array}$ \\
\hline Front & $\begin{array}{l}\text { Head erect with natural chin level, Efficiently weight } \\
\text { bearing in a perfect balance }\end{array}$ \\
\hline
\end{tabular}

Create and maintain a stable base: - The position of the feet is the secret to safe handling. The handler's feet should be comfortably apart with one foot slightly in front of the other; this gives a wider base of support and stability in all directions. The position of the feet may also enable the handler to manage a surprise or unpredictable movement by the patient. Relaxing knees and hips with an offset base can improve balance. The offset feet position also creates a greater surface area as feet are kept in contact with the floor when knees and hips are relaxed. Safe handling should always be within the handler's personal base, handling outside the base causes the handler to become unstable.

Bend the knees and the hips: - When picking an object up from the floor a young child will bend their knees and hips thereby allowing the quadriceps muscles to aid the movement, a natural movement we are all born with. Never handle in front of the knees as this makes the handler carry out the handling task at arm's length and never handle to one side of the knees as this causes the spine to rotate when handling.

Keep the spine in a natural position: - Keeping the spine in a natural position allows it to act like a spring and absorb the body weight thereby assisting the main shock absorbers, and the smaller spinal muscles, to work to their full potential. Keeping a neutral position with the natural " $S$ " shaped curves allows the spine to be a stable structure by keeping parts of the spine either side of the line of gravity. A straight upright back position makes the spine unstable as the small spinal muscles are unable to work to their potential. The spine should be kept naturally upright whenever it is possible, leaning forward through the lumbar spine, even for a small degree, can add a considerable load onto the vertebral column. A back in a natural position allows less stress on the spinal structures of the discs, facet joints and ligaments.

Never rotate or twist the spine: - Twisting or the rotational movement of the spine reduces the effectiveness of the joints and muscles and decreases the body's capacity to do work and increasing the chance of an injury occurring. If the spine is bent forward and rotated there is 
a high level of compression on the spinal structures. If the spine has to be rotated then the handler needs to reposition their feet as it is this that can cause the pelvis and shoulders not to be level. If the handler has to turn with the patient or twist the spine then the handler should either pivot on their feet or reposition their feet thereby reducing the rotational stress on the intervertebral discs.

Keep the load close: - The distance of the person from the spine at waist height can be an important factor in the overall load on spine and back muscles. When moving and handling a system of levers comes into action, with the L5/ S1spinal joint being the lower back lever joint. If the object is moved further forward causing the handler to lean forward at the lumbar spine region the handlers capability decreases. This pressure does not allow the spine to absorb the forces by compression but pulls the spinal joints apart and stretches the ligaments to their limit. It is essential to reduce the effect of excessive leverage; this is best achieved by taking up as close a proximity to the patient as possible.

On commencement of the task: - Raising of the head and shoulders enables the carer to see any hazards they may have to step over or move around at the same time it brings the cervical area of the spine into the correct position and ensures a natural position of the spine.

Lift and lower with the legs smoothly: - Flexion at hips and knees allows the muscles in the legs to perform their task; quadriceps contract, hamstrings and calf muscles relax to allow the movement to take place, this helps to prevent stress on smaller spinal muscles. The movements should be controlled and smooth.

Use your body weight: - Assisting a patient to stand or transfer requires not only muscle power but also the added assistance of the handler transferring their body weight. The basic principle behind using the handlers and the patient's body weight to transfer patients is to allow the use of momentum through kinetic energy which assists a handler to transfer a patient with minimal effort. The handler's hands and arms are used to guide a patient but the transferring of body weight and the muscle power is of major importance.

\section{CONCLUSION}

Over the years there have been many changes in patient handling equipment but the constant themes that have never changed in all those years are the basic principles of movement and handling. By following the basic movement principles, the handler is made aware of the dangers involved and is encouraged to adopt the safest position for handling the patient. This does not mean that injuries due to moving and handling will become obsolete simply by following the rules.

Healthcare professionals work with the most unpredictable load in the world, a person, and this explains why they have the highest incidence rate of moving and handling injuries. However, by following the basic principles, handlers are putting themselves into the safest handling position they can adopt. Patient handling procedures in the UK have changed dramatically since the introduction of MHOR in 1992 (revised 2004/ 2016) [17], from full body lifting to using body weight, equipment and trans- fer. Over time tasks again will change with the invention of more state of the art equipment and innovation towards moving and handling training, however the principles of movement will always continue to be the most important part of any patient or inanimate load handling.

\section{REFERENCES}

1. Dorn TW, Wang JM, Hicks JL, DelpSL.Predictive Simulation Generates Human Adaptations during Loaded and Inclined Walking. Public Library of Science One. 2015; 10: 4.

2. Asgari M, Sanjari MA, Mokhtarini HR, et al. The effects of movement speed on kinematic variability and dynamic stability of the trunk in healthy individuals and low back pain patients. Clinical Biomechanics. 2015; 30 (7): 682-688.

3. Wanless $S$. Improving the effectiveness of motor skills learning in moving and handling training for the healthcare environment. Unpublished PhD thesis, 2015.

4. Health and Safety Executive. Work Related Musculoskeletal Disorder statistics, Great Britain 2015. HMSO. London, 2015.

5. Wanless S. Hopper D. Moving and Handling Practice: The Challenge for Educators. Equipment Services Journal. 2015; 7: 44-48.

6. June KJ. Cho S. Low back pain and work-related factors among nurses in intensive care units. Journal of Clinical Nursing. 2011; 20:3-4: 479-487.

7. Castro AB. Handle with Care: The American Nurses Association's Campaign to Address Work-Related Musculoskeletal Disorders. Orthopaedic Nursing. 2006; 25 (6): 356-365.

8. de Souza Petersen R, Marziale MHP. Low back pain characterized by muscle resistance and occupational factors associated with nursing. Revista LatinoAmericana de Enfermagem. 2014; 22 (3): 386-393.

9. Lind A, Gard G. Harmful Effects in Personal Assistants' Client Transfer Situations. The Ergonomics Open Journal. 2014; 7: 1-5.

10. Bonzini M, Bertu' L, Veronesi $G$, et al. Is musculoskeletal pain a consequence or a cause of occupational stress? A longitudinal study. International Archives of Occupational and Environmental Health. 2015; 88(5): 607-612.

11. Hignett $S$. Intervention strategies to reduce musculoskeletal injuries associated with handling patients: a systematic review. Occupational and Environmental Medicine. 2003; 60: E6.

12. Bevan S. Economic impact of musculoskeletal disorders (MSDs) on work in Europe. Best Practice \& Research Clinical Rheumatology. 2015; 29(3): 356-373.

13. Parent-Thirion A, Vermeylen G, van Houten G, et al. Eurofound project: Fifth European Working Conditions Survey. The European Foundation for the Improvement of Living and Working Conditions. Luxembourg, 2012.

14. Smedley J, Williams S, D'Arcy P, et al. Back pain management: Occupational health practice in the NHS in England. A national clinical audit - round 2. London: Royal College of Physicians, 2012.

15. Unison. UNISON submission to the NHS Working Longer Review. London: Unison, 2013.

16. Wanless S. and Wanless SG. Hoisting a patient: Principles for safer practice. International Journal of Therapy and Rehabilitation. 2015; 22(8): 390- 395.

17. Health and Safety Commission. Manual Handling Operations Regulations 1992, L23 (as amended 2004). HMSO. London, 2016.

Manuscript received: 29.11.2016

Manuscript accepted: 22.12.2016

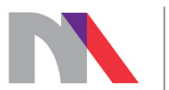

Ministerstwo Nauki

i Szkolnictwa Wyższego

„Konsultacje z zagranicznymi naukowcami i wprowadzenie dwujęzycznych (j. polski/angielski) treści do czasopisma Pielęgniarstwo XXI wieku" finansowane w ramach umowy 547/P-DUN/2016 ze środków Ministra Nauki i Szkolnictwa Wyższego przeznaczonych na działalność upowszechniającą naukę. 